\title{
Cross-Language Poetics: Proposal for an Interdisciplinary \\ Research Program
}

\author{
Norbert Francis (Flagstaff)
}

\begin{abstract}
For creative writers and for readers, opportunities to work with language in ways that engage two linguistic systems and/or two writing systems continue to expand with the growing influence of international and regional lingua francas. At the same time, we have witnessed the continuing development of literary creation in languages with fewer speakers, even in communities facing the outright erosion and replacement of their language. Alongside the tendencies of globalization, literature has also become more diverse, a new recognition of multilingualism and multiculturalism emerging among writers and readers alike. The special circumstances of composition and understanding that the different kinds of language and cultural interaction highlight also present us with an opportunity to study what it is that is fundamental in verbal art. After reviewing three historical examples of European origin (in Section 2) we will turn our attention to problems of language, writing system and poetry in East Asia (in Section 3). The examples from history will help us to put the current situation of multilingual and multicultural contexts for literature into a broader perspective. This is will allow us to return to consider a proposal for research on cross-language poetics.
\end{abstract}

\section{Introduction}

After a long development of the national literatures, a new valorization has come forward in recent years of writing in a language that is not one's mother tongue, or writing in a language that is not official, national or customary, and that may be one's first or heritage language. Lessons from history help us think about the relevant interfaces and mutual influences. Looking back more or less to the first millennium of the common era, approximately during the same period, in the Mediterranean region, Eastern Asia and Mesoamerica, great lingua francas (e.g., Latin, Arabic, Chinese, Nahuatl) had become predominant, if not exclusive, media of poetic and narrative discourse. The analogy with the spreading influence today of English is interesting, because the current internationalization of communication in the humanities and science is accompanied by, and combined with, a concurrent diversification. Today, we are witness to the continued flowering of indigenous and vernacular genres of verbal art in the context of a growing recognition of multiculturalism and language diversity. Notably, the realm of international scientific discussion shows the opposite trend, a progressive narrowing toward the use of fewer international languages, responding in large part to specific communication needs of scientists, in any case the topic of a separate discussion. 
Experimentation in bilingual poetry, cross-language creative writing of other kinds, and intercultural expression and artistic communication overall is taking on growing importance in literary practice and analysis. This is because of the unfolding of the two contemporary developments just mentioned: internationalization and diversification. At first glance, this claim appears to be contradictory given the accelerated decline and imminent extinction of hundreds of indigenous languages worldwide. The contradiction, however, is only apparent, access to new language processing technologies being the decisive factor accounting for both tendencies, both internationalization and diversification. The recently inaugurated indigenouslanguage internet channel, TV Malintzin, from Mexico, is one especially innovative example, among others, featuring the digital compilation and dissemination of a vast corpus of narrative and poetic genre.

For language learners, to take one example of cross-language interaction, bilingual poetry (and bilingual literacy in general) is considered today as a resource that favors the development of advanced proficiency in all realms of language use. This idea, in turn, suggests a number of new research questions in the study of literature. In the case of readers whose current primary language is not their mother tongue, what is the role of transliteration and different kinds of translation and transposition in cases of a difference in writing system (Kenner/Al-Azami/Gregory/Ruby 2008)? ${ }^{1}$ Does composition in one's non-primary language provide for creative opportunities that are exceptional in some way? In this regard, it is widely understood that creative writing partakes of special resources when it deploys grammar in verse form. Thus, can the language learner or non-native speaker exploit these resources successfully for literary purposes? As is also generally accepted, the related problems of translation in poetry present specific conditions of interface between languages, somewhat different from those in the prose genres.

To consider another example, in the transition/transcription of oral tradition poetry, interesting dilemmas come to light for speech communities with recently adopted writing systems. What trade-offs and compromises do traditional poets face when literacy is introduced, and can they even be avoided (Johnson 2006)? Related to this transition/transcription, when different stylistic norms come into contact cross-culturally, new borrowed and hybrid forms emerge; others are preserved intact, abandoned or suppressed. How are these transformations to be interpreted? For example, see the discussion in Webster (2009) on the evaluation of aesthetic devices such as ideophony in traditional and modern Navajo poetry. Surviving vernacular poetry, as in ritual discourse, presents unique examples of bilingual and multilingual contact of its own kind involving language systems that are sometimes only partially intelligible (Wirtz 2005). These exceptional uses of language for aesthetic purpose call our attention to the musical foundations of poetic expression in general, in turn presenting considerations not even relevant to transcription or translation, in the usual sense.

\footnotetext{
${ }^{1}$ An important distinction is made between writing system and script (cf. Perfetti 2003). Within the category of a writing system different types of script implement its common principles, how linguistic units are represented orthographically. Thus, Roman, Hebrew, Arabic, Korean (hangul) and Cyrillic are examples of scripts that all follow the general principles of alphabetic writing (individual graphemes represent phonemes). Japanese katakana and hiragana are examples of scripts of the syllabic (or moraic - see Note 6) kind - graphemes correspond to morae. Chinese uses a morphosyllablic system.
} 
Lastly, for now, the question of style-switching (within the same language) leads us to new issues in mixed-language verse. Conceivably, the constraints on the integration of embeddedlanguage patterns into the matrix language ${ }^{2}$ of a poem would not be the same as (but not different in every way from) the constraints on borrowing or insertion in everyday conversation and prose narrative. For example, embedded-language patterns refer to constituents from Spanish inserted into verse executed predominantly in English, or vice versa, characteristic of bilingual poetry in the United States composed by bilingual poets. After considering examples of language mixing in creative writing, a proposal for research on this aspect of cross-language poetry will be presented in Section 4 (see also Note 9). The analysis of specific cases will be deferred with the hope that specialists in the field of codeswitching might take up this proposal. The more general problem of language choice in highly diverse multicultural/multilingual situations, including dialect variation and author's first and second language competence (Gargesh 2006), allows us to apply the important concept of diglossia (and digraphia) to creative writing. Implicit in this last example is the question of whether poetic forms lend themselves more readily, or more productively, to crossing language boundaries. This question will become the overarching theme of the proposal to be offered in the next sections and in the conclusion.

The following historical overview of cross-language contact from vastly different intercultural circumstances, in Sections 2 and 3, will suggest a series of interesting research problems as creative writers continue to explore bilingual, second language, and multilingual contexts for their work. Choice of writing system and script is an important aspect of understanding how interlinguistic and intercultural factors affect both expressive and receptive processes. This is the aspect of cross-language poetics that we will mainly attend to. A better understanding of the interaction between language and writing system in bilingual and second language creative writing will also help frame speculation on what the foundational properties of verbal art might be. Section 2 examines three cases of intercultural and cross-language literary creation, centered on the dispersion of Spanish beginning during the 15th and 16th centuries: Subsection 2.1 - the use of Hebrew script for poetic texts from Iberia, Subsection 2.2 Arabic script for the same genres, and Subsection 2.3 - the Roman alphabet for creative writing in the indigenous languages of the Americas, coinciding with the introduction of Spanish, and Latin, to the New World. Section 3 shifts the discussion to East Asia with a focus on the influence of Chinese writing in Japanese poetry: Subsection 3.1 - how diglossia and diagraphia characterized the early language contact situation between Chinese and Japanese, Subsection 3.2 - the evolution of Chinese literature and writing in Japan, Subsection 3.3 - how in this historical context the concept of cross-language intertextuality can be applied to poetry, and Subsection 3.4 - how to better understand the exceptional features of Chinese characters regarding their use in creative writing.

\footnotetext{
2 From the study of bilingual speech, the broadly useful analytical categories of embedded constituent and matrix framework are taken from Myers-Scotton (2006). Mendieta-Lombardo and Cintrón (1995) discuss an application of Myers-Scotton's model to bilingual poetry related to the concepts of markedness and audience awareness.
} 


\section{$2 \quad$ Three examples from 1492}

A fateful year marked Columbus's landfall where he claimed the New World in the name of the monarchs of Spain. For the Spanish language, it coincided with the publication of its first grammar, Antonio de Nebrija's Gramática de la lengua castellana. The year that announced the expansion to the Americas of the first (now linguistically described) European national language also initiated the cultural and linguistic cleansing of the Iberian Peninsula, beginning with the Sephardim, to be followed some years later by the expulsion of non-convert Muslims. Spanish spread to the West by exploration and conquest, to the East by exile.

\subsection{Hebrew alphabet for Spanish}

In medieval Spain, as the Reconquest advanced southward, the Jewish population progressively shifted from Arabic-speaking to one or another of the Iberian Romance languages. For writing, the Hebrew script served both the former and the latter. Thus emerged the particular cross-language resource, known as aljamía (adjective: aljamiado/a, to describe a text of this kind), that characterized the literature, and all other written genres, of JudeoSpanish. This literature in transcription flourished, with predictable ups and downs, for centuries, in the eastern diaspora, accompanying the same fate of Judeo-Spanish itself (Minervini 2006; Zucker 2001). Today in advanced stages of erosion, in all parts of the world where it is still spoken, the important scientific question is how it was able to prosper for so long. In this regard, much sociolinguistic speculation on some of the details of language and script choice, which may have contributed to its loss, is entirely theoretical, and again purely speculative. The breakup of the Ottoman Empire, and with it the favorable multilingual and multicultural conditions that prevailed (Kánchev 1999), marked the turning point. Late 19th and early 20th century nationalism attempted to restrict publication in foreign languages and foreign scripts, the Holocaust, ending in 1945, dealing the decisive blow. Subsequent strong assimilative pressures, unfavorable objective conditions of dispersion, and non-inclusive language policy in receiving countries, e.g. in the Americas and Israel, ensured the marginalization of Hebrew script aljamía and Judeo-Spanish itself. Surviving literary production today utilizes a Roman alphabet, visibly distinct, interestingly enough, from the orthography of modern Spanish (Czöndör 2008).

Perhaps the most well-known, and in some ways most interesting, accomplishment of Sephardic literary (re)creation was the preservation of Spanish ballad of medieval origin (the romances) into the 20th century, retaining compositions and fragments that had apparently been lost in the motherland itself. Primarily by means of the vehicle of the oral tradition, e.g., mothers' lullaby (Díaz-Mas 1993; Harris 1994), the most characteristically Spanish genre of all was most faithfully conserved. But as Díaz-Mas points out, it would not be correct to assign exclusivity in this regard to the traditional musical medium of oral transmission. Successive waves of exiles during the $16^{\text {th }}$ century carried with them manuscript versions in aljamía, Moroccan communities recorded their romances by hand, and the prolific press of the eastern urbanized diaspora disseminated them widely in chapbook format. For the great majority of exiles without formal education, Judeo-Spanish was their primary if not only spoken language and Hebrew script the primary access to literacy. A true irony of language and orthography we could speak of in this instance of poetic inheritance and continuity. The Roman, or Latin, script associated with Christian Spain and exclusion, turned out not to be an 
adequate medium of Spanish literary heritage in exile. Writing and literacy turned out not to be the most faithful guardians of the traditional poetry on the Peninsula either. In contrast, the language itself served this heritage tenaciously (Díaz-Mas 2005; Zucker 2001), even though as a linguistic vehicle it was of a divergent, non-standard, dialect, expelled from Iberia to be preserved elsewhere, in oral tradition and a non-Latin script, where it did come to be published.

Mainly transmitted by writing were the poems of early Spanish origin (coplas), in stanzas for singing, varying widely in length. Typically on religious themes, through the coplas is where we would find the strongest poetic legacy of the Sepharad and linguistic and stylistic influence from the Hebrew language itself, in addition to Arabic, hypothetically facilitated by the use of the Hebrew script. The most noteworthy exemplar is the $15^{\text {th }}$ century aljamía version of the biblical legend Poema de Yoçef (Girón-Negrón/Minervini 2006), over 300 quatrains long.

Hebrew writing in general served as a conduit of both traditional and outside influence to the culturally isolated Mediterranean and Balkan communities, for example, strangely enough, for the translation of Spanish literature of the Golden Age. Liturgical poems were influenced by the romances and vice versa for popular poetry and song (Díaz-Mas 2003). With expanded literacy creation and increased production by the printing houses, tendencies toward regional standardization appeared. At the same time, with the different dialectical variants in constant contact with the languages of the Ottoman Empire, a proliferation of norms held convergence and standardization in check. The effect of this diversity on creativity and productivity in aljamia literature overall is difficult to assess. The effects, on balance, may not have been negative at all judging by the proliferation of publishing up to and including the decades preceding World War II (Harris 1992; Minervini 2006). For creative writing in vernacular and non-standard language varieties, a number of interesting problems related to standardization still remain as open questions for further research. See Romero (2010) for an interesting review of the intense debate in the Sephardic press on the question of the use of JudeoSpanish during this period. Aside from the role it played in valorizing and conserving Sephardic culture and language through literature, what specifically aesthetic resources might the use of the Hebrew script have provided to writers?

\subsection{Romance languages in Arabic script}

Similarly as in the case of the Sephardim, with the advance of the Reconquest, Muslims who progressively came under Christian rule began to acquire the Romance languages as their mother tongue. Depending on political and military circumstances, spoken Arabic and classical Arabic in writing were maintained for much longer in some regions than others. Bilingualism, however, would have been more widespread than in the case of the Spanish Jews given the strong identification on the part of both Moriscos ${ }^{3}$ and practicing Muslims with the continued high-language status of Arabic, despite persecution and discrimination. Recall also that leading up to the final surrender of Granada in 1492, Arabic was still the

\footnotetext{
3 Muslims who were obliged to convert to Catholicism during the Reconquest were called Moriscos (conversion typically being nominal), not to be confused with Mudéjar, the Iberian Muslim who came under the rule of Christian authorities. While, and in the regions where, tolerance of Islam persisted, until 1502, the Mudéjar community was allowed to practice its religion.
} 
language of the realm in the regions yet to fall to the Reconquest. Naturally, Arabic-script aljamia $^{4}$ emerged earlier where the popular classes shifted to a Romance language first, as in Castile and Aragón. The use of Arabic was eventually outlawed (mid-16th c.), with the series of displacements, internally, from one kingdom to another, and expulsions from the Peninsula altogether, culminating in 1609.

Predictably, the exile communities traversed very different conditions of integration from those of the Sephardim if they settled where Islam was predominant, as was typically the case. Most notably, regarding our topic, the use of aljamia, instead of expanding, rapidly declined, again for predictable reasons. Spanish-speaking writers (e.g., former Moriscos) soon after expulsion began to prefer the normal Roman alphabet, having no reason any longer to symbolically defend their specifically Iberian-Islamic cultural and written language heritage against successive prohibitions by Christian authorities. Besides, aljamía would have gained few new readers among local native speakers of Arabic, worse yet, lending itself to serious misunderstanding (Chejne 1980; Gómez Renau 2000; Vespertino Rodríguez 2007).

Indeed, prior to 1609, writing in Castilian or Aragonian, in the script of the holy language of Islam, was a symbol of no small consequence. Bouras (2009) proposes a series of stages in the evolution of Arabic-script aljamia, beginning in 1455 with the translation of the Koran by Içe de Gebir, ushering in a "Castilian period," ending in 1501. The celebrated Poema de Yuçuf, estimated, controversially, to have been transcribed during the $14^{\text {th }}$ century, would push back the emergence of aljamía much earlier. These years represent a link to the final stage in exile; texts from this period were later put to verse and eventually carried by Aragonian refugees to Tunis. An "Aragonian period" (1501-1525) received this literature from Castile where increased restrictions impelled migration to the more tolerant realm, during this time, of King Ferdinand. The stage of "forced Christianization" (1526-1609) is probably when many of the texts were hidden, often not recovered until centuries later, if they were. The "exile period" in North Africa marks the beginning of the erosion and final displacement of Arabic-script aljamia (Spanish to be written in the Roman alphabet, Arabic in Arabic script). It was a literature of the last Spanish Muslims, during the years leading up to expulsion, clandestinely hand written as a way to preserve a cultural identity and fidelity to their faith. Its actual deployment probably evoked a measure of ambivalence as the orthographic form corresponded to deep-felt commitments about language and religion. In fact, its themes were predominantly religious (Bouras 2009; Gómez Renau 2000).

Reflecting the gradual and inevitable disappearance of the Morisco culture, aljamia literature also freely accepted linguistic influences (in both grammar and vocabulary) from Arabic, facilitated by the use of its orthography. At the same time, it expressed and carried forward

\footnotetext{
${ }^{4}$ A curious mutual disconnect the non-specialist reader often encounters in the professional literature. To study the research reports on the emergence and development of either Muslim-Spanish or Judeo-Spanish aljamía, one may mistakenly conclude that the writing of Spanish in foreign writing (derived from the Arabic: alajamia, to refer to non-Arabic languages) was exclusive to either Arabic or Hebrew script. In fact, aljamia refers to both. Similarly, there are two non-Roman script versions of the Poem of Joseph, each in its respective aljamiado text, by any account a very interesting detail, often omitted. The running total so far then is three versions, including the one in Roman script. Ironically, this makes Spanish in Iberia before 1492, despite the violent upheaval of the epoch with all its misery, intolerance and persecution, an important historical meeting place for the three great monotheist cultures in the eloquent legend in narrative verse that they all share. Each of the texts (while
} 
the Iberian cultures and languages, not foreign or alien to the Moriscos, being their cultures and mother tongues as well. The highly complex, conflictive and ever-shifting multilingualism of Spain and Portugal had rendered language boundaries diffuse and ambiguous. The use of alternative scripts (Arabic and Hebrew) was part of this diffusion, itself participating in the mutual influence, transfer and interference of many kinds. A case in point was the extensive borrowing and codeswitching between Arabic and Romance languages in verse forms such as the jarcha, evidence of widespread bilingualism among composers and their audiences (Kettani 2007; Liman 2002).

As was alluded to in the previous section, surely one of the crowning attainments of aljamía literature, shared by both Hebrew and Arabic-script traditions, was the Poema de Yoçef/Yuçuf. Circulating more or less during the same period, the different versions generously borrowed thematic, linguistic and stylistic elements from among themselves, an extended exchange of true cross-language and cross-cultural intercommunication with deep roots in medieval Muslim Spain (González Palencia 1928). A narrative poem in cuaderna vía (four-line stanzas), based on the story of Joseph from the Koran and Genesis, it was apparently esteemed for its lyricism, evocation of strong emotion, poetic description of surroundings, and metrical qualities (Pérez Lasheras 2003), distinctly departing from the genre of the time. Menéndez Pidal's (1952) analysis of the Arabic-script text, attributed to an anonymous Aragonian author, indicates an early transcription from the oral tradition version during the $14^{\text {th }}$ century. Written for Morisco readers, the manuscript came to be wrapped in cloth and buried, not to be discovered until the 1800 s.

In the end, the literature was either hidden from the Inquisition, destroyed, or taken into exile. Further research on the loss of Arabic-script aljamía as the Moriscos became integrated into the North African communities that received them should provide us with another interesting example of cross-language interaction involving different writing systems and orthographies.

\subsection{Orthography and bilingualism in the New World}

Spanish traversed the Mediterranean and the Atlantic during the same years. In the Americas, cross-language literature exploited the flip side of aljamía: instead of different scripts sharing the same language, the same orthography was pressed into service for writing in the different Amerindian languages. In addition, another kind of transcription, also different from the one we just considered, was at the center of cross-language communication: the recording, for the first time for most indigenous cultures, of oral tradition poetry.

By many accounts, the highest expression of poetic creation, widely translated and read still to this day, is the Popol Vuh. Aside from being the most famous of the origin myths of the Americas, our interest in the work centers on the exceptional circumstances (for the New World) of its composition. While early translations of the Quiche Mayan text conformed to a prose narrative form, more recent editions have emphasized its poetic features, in particular an elaborate parallelism, Christenson (2007), for example, identifying examples of fifteen different types. In this case, the use of merismus (denoting or evoking a broader idea with a pair of narrower subset elements) appears to be related to the prominent Nahuatl literary

superficially, to the eye, appears different from the others) is about the same José/Yoçef/Yúçuf, in the same language, more or less. 
device of disfrasismo; see Note 5. The most common stanzaic arrangement is the parallel couplet, a discourse form evidenced in modern ritual speech and even sometimes in everyday conversation when attention is called to wording itself.

The theory that an ancient text version of the Popol Vuh was composed by the Maya, that exemplars survived the collapse of their civilization and were conserved by communities through to the years prior to the Spanish conquest is entirely plausible. The Mayan logosyllabic orthography was by far the most advanced of the New World, constituting a complete, linguistically based, writing system (Coe/van Stone 2001; Rodríguez Martínez et al. 2006; Vail 2006), building on precursors dating from the early first millennium BCE. However, we lack evidence that an original manuscript of the legend ever existed, or that one had escaped the early colonial purges of Mayan literature to have then served as a base document for transcription. Composed in alphabetic script by an anonymous 16th century writer with either access to the hypothetical codex or a full oral tradition version, a Quiche language text of the Popol Vuh was either hidden or circulated under the radar in the Mayan communities for approximately 150 years. It was conserved long enough for Dominican missionary Francisco Ximénez to have copied and translated it during the first decade of the 18th century (López 2009).

The poetry of the Spanish conquest-era Nahuatl-speaking cultures comes to us through a different route. As with the legacy of Mayan writing, it is important to always keep in mind that our theories on all aspects of the literature of Central Mexico and its graphic systems remain tentative given the massive destruction of libraries following the fall of the Aztec capital in 1521. Nahuatl literature was reconstructed by bilingual missionaries and their native-speaker assistants assigned to this task (our second irony of language and orthography). Unlike in the case of the Mayans, the surviving, and recreated, codices of the Nahuatl-speaking peoples did not show evidence of a complete writing system, rather one that was perhaps evolving toward one (characterized by the use of predominantly pictographic and logographic symbols). Incipient phonological components began to appear as rebus graphics (e.g., pictograph for deer [mazatl] superimposed on a pictographic glyph indicating teeth [tlantli], the latter suggesting the locative homonym [tlan] $\rightarrow$ Mazatlan = Deer-place). Informants educated in the pre-conquest calmecac system, typically from the former nobility, dictated in Nahuatl to the missionary scribes. With access to codices (largely also reconstructed post-conquest by indigenous chroniclers), they used these graphic representations for mnemonic support, supplementing their extensive knowledge of oral tradition poetry. Crucially, a generation of native-speaker writers (graduates of the first institutes of higher learning such as the famed Colegio de Tlatelolco) rapidly appropriated the alphabetic system and composed works independently (Garibay 1989; León-Portilla 1996).

The large and varied poetic literature of the Aztecs, destroyed and partially revived by the cataclysm of the Conquest, now recorded in an alphabetic script, allowed scribes, scholars and new poets to make visible its verse structure. Our ability to study it today we owe to the monumental undertaking of the surviving indigenous poets and informants and their colleagues among the illustrious humanist friars of the day. (Note that not all of the Spanish missionaries of the 16th c. belonged to this intellectual elite of Nahuatl linguists and pioneer ethnographers.) One cross-language hypothesis is that the elaborate and multivariate parallelism of Mayan verse forms was a heritage passed down to the Central Mexican 
cultures. A pervasive characteristic of Nahuatl poetry, this universal aesthetic recourse is implemented at a number of levels and in different combinatorial patterns. Perhaps the most distinctive type, as mentioned earlier, is the disfrasismo (Montes de Oca 2009), similar to merismus. In this case, the trope involves a kind of conceptual compounding in metaphor construction.

(1) In poctli ehuatoc ayahuitl on mantoc

[The smoke rising up, the fog extending over] - parallelism (in general)

In Cantares mexicanos, from a poem that contemplated the scene of the desolation of Tenochtitlan after its fall to the Spanish and their indigenous allies, quoted in Garibay (1971)

(2) In ehecatl in chichinaztli

[the wind the ardor $=$ sensuous pleasure $]-$ disfrasismo $^{5}$

(Garibay 1971: 19)

In a separate observation, Leon-Portilla and Garibay call attention to the insertion in verse lines of non-word expressions. If their function was metrical and/or to provide for intonational contour, this would lend support to the idea (hypothetical, strictly speaking) of the versification of transcribed/reconstructed texts. Evidence strongly suggests that Nahuatl poetry was completely integrated into dance and musical performance contexts (León-Portilla 2007).

An interesting debate, closely related to our interest in the consequences of the crossover to alphabetic writing, concerns the degree of distortion that was effected by the work of compilation and transcription; see Hadley (2008) for discussion that includes considerations pertinent to modern indigenous literature, and Damrosch (1991), Johansson (1993) and Lee (2004) for alternative perspectives. Indeed, it is a safe assumption to make that the overriding motivation of the friars in preserving and publishing the literature of the indigenous cultures was the mission of evangelization. But León-Portilla suggests another (not counterposed) vantage point on the questions of trustworthiness and contamination regarding the fidelity of the transcribed texts. Our present focus on poetry, parenthetically, coincides with such a complementary view to the problem of authenticity (it complements because the relevant distortions in transposition are still important research questions). The interpretation of the codices and simultaneous transcription was the most eloquent material bridge that brought the European and American traditions into contact (as imbalanced and unequal as this transaction was from the beginning). As such, the new contaminated literature, as it were, was also an aesthetic object it its own right. From this point of view, the poems are works of verbal art just the same, deserving of a thoughtful retrospective (conceding and acknowledging in historical perspective the unequal transaction, in which, to be sure, the alphabet participated).

\footnotetext{
${ }^{5}$ Disfrasismo is carried over into poetic uses of language in ceremonial discourse (Oca de Vega 2009) and in everyday speech:

in atl in tepetl

[the water the mountain $=$ town], commonly contracted to altepetl. As an agglutinative language, Nahuatl makes highly productive use of this kind of compounding, a grammatical feature clearly providing a platform for the stylistic option in its literature:

altepetl + tlacatl $=$ altepetlacatl

[town + man $=$ layperson, a man who doesn't belong to a religious order].
} 
Recall that the Popol Vuh, along with other Mayan masterworks, was also composed/transcribed, in alphabetic Quiche, during the Christianization period, in its case most likely independently, without the participation of bilingual friars. Indigenous Nahuatlspeaking writers went on to do the same as they shifted to alphabetism as soon as the opportunity presented itself. Cultures and literatures are never static, especially when they come into contact with others. Five hundred years later, indigenous language-speaking poets in Mexico continue to exploit the same writing system, as they have attempted to revive the example of colonial 16th and 17th century indigenous language literature, which in fact continued to develop under Spanish colonial rule, up until it was suppressed many years later. Montemayor (2005) reviews recent developments and topics for further study.

\section{$3 \quad$ Lingua franca in East Asia and Japanese poetry}

Our final historical example of cross-language literary creation involves a writing system with completely different characteristics from those shared by the alphabets of Iberia and the New World. As Arabic, Hebrew and Spanish were languages of art, erudition, religious faith, or of empires in ascendancy, during the time of Muslim Spain in Europe, the Chinese culture had emerged as the most advanced in the Far East. Similarly to the case of the languages of the Americas that we just reviewed, this section will also take us to the present day; but in contrast to all the previous examples, in the end, this example is not that of an exiled or colonized people or of a minority/indigenous language.

\subsection{Diglossia and digraphia}

By the 6th and 7th centuries, Japanese poets, without a writing system of their own, had welcomed the introduction of Chinese literature as part of an extensive sinicization of society, to include in coming years a massive influence in the lexicon of the language itself. Chinese characters, kanji, were adopted along with the Chinese language for writing in a clearly defined diglossia, the Japanese language reserved for non-literate domains.

Since kanji is morphosyllabic, with no alphabetic features of individual phoneme-grapheme correspondence, a kind of concurrent translation (of a special kind) to Japanese came to be feasible and could supplant Chinese readings of kanji texts modified for this purpose. One approach to Japanese reading/transposition, among others, was that Chinese characters could either stand for their semantic value (and pronounced in Japanese), or for their (Chinese) phonetic value written to represent Japanese syllables (strictly speaking: morae). ${ }^{6}$ These processing resorts soon lead to the emergence of pronunciation diacritics and adapted characters for representing Japanese function words, inflections and other grammatical morphemes. Over time, the system of using modified kanji for their phonetic value, known as man'yôgana, lead to the development of the fully formed native language-based syllabaries,

\footnotetext{
6 The mora is a phonological unit that often coincides with the syllable unit, but is considered a "timing unit." So, "if two sets of three-mora words are compared with respect to their length, the general durations ... come out more or less the same" (Tsujimura 1996: 66). For example, in regard to duration, long vowels and diphthongs form two morae, short vowels, one mora: Tôkyô: to-o-kyo-o (2 syllables, 4 morae) Nagasaki: na-ga-sa-ki (syllables and morae coincide). Consonants can also be long and short (in regard to duration): sakka [author] vs. saka [hill] (p. 16). Thus, gakkoo [school] has two syllables, but four morae: ga-k-ko-o (p. 66).
} 
the kana (katakana and hiragana), so that by the 10th century kana could serve as a complete writing system for Japanese, including for the highest forms of literature. In the end, hybrid kanji-kana text became the norm, continuing to the modern day, following rises and declines from one historical period to another in the ratio between the two orthographic subsystems (with the long-term tendency marking a gradual decrease in kanji use). The exceptionality of Japanese writing resides in the preservation of kanji, as the kana system came to be fully established, as bilingualism (in Chinese) declined, and the Japanese language sufficing completely for the decoding of all genres, scripts, types of character and style, including kanji-only texts. For poetry, as well as for other domains, this duality flowed from the continued high esteem in which Chinese literature and culture was held, to be held thus for many hundreds of years even through long periods of isolation from the Asian mainland (Gottlieb 2005; Loveday 1996; Watanabe 2002).

\subsection{Chinese literature from Japan}

Preserving the hybrid system originating in the ancient introduction of Chinese characters is also what is interesting from the point of view of our theme of cross-language poetics, in particular certain aspects of the survival of the kanji subsystem for creative writing in the face of the fully productive syllabaries (the kana). The mid-8th century marked an early pinnacle of Japanese literature with the compilation of the first anthology of kanshi [Chinese-language poetry], the Kaifûsô, and the appearance only a few years later of the Man'yôsh $\hat{u}$, an anthology of 4,500 poems in Japanese (S. Kato 1997). Here it is important to be mindful of a distinction between the Chinese verse of Japanese poets, composed in the Chinese language, and Japanese-language poetry written in Chinese characters. At the same time, a moment's reflection suggests to us that the distinction is not as sharp as it appears at first glance. Conceivably, taking the diverse corpus of all kanshi compositions, there would be a continuum of accessibility to them on the part of the hypothetical (monolingual) Japanese reader, skilled in reparsing Chinese phrase structure and in mentally vesting it with the required grammatical constituents. Such a scenario assumes a historical period subsequent to the sharply demarcated diglossia of the earliest years of Chinese influence when literacy also implied knowledge of the Chinese language itself.

In reality, texts in kanji came to present a wide range of orthographic options for Japanese readers. In addition to the kana and their precursors mentioned above, a system for modifying kanji was perfected to facilitate Japanese readings, the kambun kundoku [Chinese read in Japanese manner], in theory still available for transposing/annotating Chinese writing today, a modern version officially standardized in the early 1900s. A typical implementation of this system of modifying Chinese characters annotates the text with: (1) punctuation, subscript index markers and characters that help readers decode sentences according to Japanese syntax, (2) kana diacritics that indicate inflectional endings and function words, and (3) pronunciation glosses where and if necessary. Alternate methods rewrote kanji in Japanese word order. In a style of highly nativized Chinese (Sinico-Japanese), writers introduced large numbers of borrowed lexemes and expressions along with a strong shift toward Japanese grammatical patterns, forming a truly combined and syncretic system. Japanese-language literature could thus be composed with this combined script, as with kana, by writers with 
only partial knowledge of Chinese. A great diversity of solutions to the problem of interlanguage and cross-cultural communication came to be devised, resulting in a continuum of cross-language access (Rabinovitch 1996; Wakabayashi 2005). Plausibly, the (also monolingual) Chinese reader of a Japanese-language poem, composed in one of the variants of kanji, would encounter a similar variation in comprehensibility, depending on different circumstances. A discretely annotated kambun kundoku that maintained Chinese syntax would be reasonably transparent, a highly nativized Sinico-Japanese, less so.

A number of complicating factors enter into the above considerations; nevertheless, the questions posed present interesting research problems for future investigation in comparative literature and cross-language philology. For example, the research questions would not be the same as those that arise from the comparison of the various alphabetic scripts of the Mediterranean and the Americas. The questions would also be different from those that arise when considering the degree of accessibility to texts in a lingua franca such as Latin on the part of speakers of the European vernaculars. Another set of research questions (not different in all respects) arises when we consider the degree of transfer between reading and writing ability in modern kanji and the different Chinese character scripts in use today elsewhere (Mainland-simplified, Taiwan-traditional, Hong Kong variant). More than a thousand years of parallel and diverging adaptation, modification and standardization have taken all of the scripts of Chinese origin in different directions. For example, can we identify degrees of accessibility of a Chinese-language text for a kanji-literate reader (who only speaks or understands Japanese), and vice versa, for different kinds of written discourse and under different conditions of written language processing? ${ }^{7}$ In this regard, would poetic genres present circumstances distinct, in some important way, from those of other discourse types? These questions fall under the purview of the psycholinguistics of bilingualism and literacy (T. Kato 2005; Kess/Miyamoto 1999), and need to be deferred for now.

The complex and fascinating early parallel development of kanshi and Japanese-language poetry, waka, is a topic of a separate discussion that we will touch on only briefly. For now, what calls our attention is the continued interest in the former even through periods when contact with China had been interrupted, and then into the modern era. As was mentioned in Sections 3.0 and 3.1, for the opportunity to participate in a more advanced culture, Chinese poetry was central to literary life. The case could be made that it was essential to the development of Japanese literature in the early medieval era (Rabinovitch/Bradstock 2005). Even as creative writing shifted predominantly to native poetry, in both quantity and quality, kanshi remained an integral part of Japanese culture. Interestingly, this admiration and commitment was in large part autonomous, not the result of continuous exchange with the mainland. Prominent Chinese poets typically did not take notice of literary developments for extended periods. Watson $(1976,1968)$ points out that for Japanese writers kanshi represented an intellectual challenge and chance to explore poetic forms thought not to be available in the native language. It came to be a mark of cosmopolitanism to master Chinese verse, a

\footnotetext{
7 The question of the degree of cross-linguistic transfer and accessibility that morphosyllabic characters afford is related to the claim that the Chinese writing system serves as a communicative resource that bridges significant language barriers (not just mere dialectal variation) among the nationalities of the Peoples Republic of China (Li 2006).
} 
disposition that later on would serve the cultural elite well in their contacts with the West. Noteworthy here is that much of Western knowledge of Chinese poetry was transmitted via Japan during the Meiji era (1868-1911); for one, poems lost in China had been conserved for hundreds of years in Japan.

Native literary expression undoubtedly was enriched by the close and long-term interchange between kanshi and waka. The perceived elegance and conciseness of Chinese verse, and the idea that poetry needed the incorporation of special forms with unfamiliar and foreign properties (foreign here surely being a relative notion) contributed to the durability of the exchange. Experimentation with intermediate and interlanguage mixed structures was part of the recreation of native poetry; kanshi and waka from the mid-8th century were never separate and closed systems. For example, solutions needed to be explored for the crosslinguistic grammatical dissidences that would inevitably arise between two unrelated languages. In a kambun kundoku reading, evidently, the rhythmic and other musical features of Chinese verse could not be preserved: asymmetry in syntactic pattern, and in how lexical tone (from Chinese) would be incorporated into Japanese verse prosody, for example. The more elaborate functional categories of Japanese grammar affect how themes are expressed and distributed across lines (or phrases), a factor related to the conciseness feature of Chinese poems; and phonological parallelism (especially open syllable rhyme) cannot be deployed in the same way. In this give-and-take, kanshi is progressively appropriated and nativized as well. Coincidently, later attention to Chinese poetry, as during the Tokugawa Shogunate (Edo period, 1603-1868), was motivated by a greater interest in the formal elements of poetry (Watson 1976). Keeping in mind that with a steady long-term decline in bilingualism, kanshi was being composed more and more by writers with decreasing approximation to nativespeaker competence in Chinese (Rabinovitch/Bradstock 2005; Watson 1968, Yoshikawa 1955). From one point of view the deviations from proper Chinese could be understood as second language learner error, but from another point of view (not necessarily counterposed to the first) as a source of innovation and productivity. Recall that we introduced this interesting question (the interaction between error and artistic license) in Section 1.

Kanshi rendered in kambun kundoku became an independent genre onto itself, not a simple translation (on this point especially, see Wakabayashi 2005), exploiting for aesthetic purpose the resource of language mixing and codeswitching, sometimes even at the expense of intelligibility. In an analysis of an Edo period poem by Kan Chazan, Sato (1998) calls attention in the Japanese-language version of a strong grammatical compression (to approximate the style of the Chinese original) and the interesting marked language choice of leaving common everyday terms untranslated (pp. 18-21). Far from always adhering to traditional motives, didactic and doctrinal, and neo-Confucian, Buddhist and classical Chinese themes, kanshi also evoked depictions befitting of emotive lyricism. On the occasion of the death of her brother-in-law, the renowned kanshi poet, Ema Saito (1787-1861) wrote:

To my sister

Your bedroom empty, you no longer draw eyebrows.

I'm glad for I've been like that for years.

We two sisters draw close to each other by a low lamp

Every evening, desks side by side, to read T'ang poems. 
(in Sato 1998: 79)

Notwithstanding its diverse strains, Chinese verse still continued to be associated with "high purposes" such as the nationalist causes of young samurai poets. In the times of crisis and upheaval of the late Edo period, kanshi was prized as especially suitable for "accommodating intense feelings and inflamed passions" with its distinctive tonal features and ardent and noble style (Fraleigh 2009: 119). Meiji era kanshi continued to be far-reaching and diverse; but with the opening to foreign influence from non-Chinese literatures, it would begin to give way as a prestigious poetic genre, declining steadily through to the end of the 20th century. As an interesting footnote, among the most compelling kanshi of this period, poems compact and unadorned, were those written by Japan's foremost novelist, Natsume Soseki, during the final year of his life (Yiu 1998).

A decidedly minority art form today, seemingly unexpected outcroppings of performance and creation of Chinese-poetry-in-Japanese make their appearance. For example, among immigrant communities in North America, a widely commented instance was the revival of shigin, a chanted variant, among detainees of the Manzanar internment camp during the 1940s. Active websites, e.g.: http://www.shigin.com/ and http://www.kangin.or.jp/ and what appear to be hundreds of postings on YouTube and other internet venues point to a research opportunity that appears to have been somewhat neglected, judging at least from a search of English-language professional journals. The shigin form, written in kanji with vocal annotation and subscript word order indices to the left of characters to facilitate recital in Japanese, consists of lines equal in number of characters, either five or seven. Thus each line constitutes a separate musical phrase. The most common form is the four-line zekku, followed by the eight-line rishi form. Of ancient Chinese origin, precursors of shigin probably crossed over during the early years of contact with the mainland when oral tradition chanted and sung verse was still an important poetic genre (Addiss 1997), prior to the widespread acquisition of writing. By some accounts, the modern form was perfected by late-Tokugawa samurai, employing a relatively fixed melodic pattern, subject to minor variation in performance, melodies based on a pentatonic scale (Gold 1975).

\subsection{Cross-language intertextuality for creative writing}

The historical duality of Japanese writing and literature reflects an approach to continuity in which innovation profoundly incorporates advances from previously developed cultural models, as opposed to overturning them, or incorporating them in only a superficial way (S. Kato 1997). This is the story of the long-term cultural and linguistic exchange with the Asian mainland, nowhere more visible than in the evolution of kanji and its various adaptations. Its use for poetic composition appears to be where the cross-language duality persisted for longer than in any other domain of literacy. In her study of hentai kambun [variant Chinese] of the Heian period (794-1185), Rabinovitch (1996) goes as far as to suggest, convincingly for sure, that the effect of the various adaptations of Chinese writing for Japanese reading was to break down for readers any clear boundary between Chinese and Japanese compositions. In addition, linguistically, the cycles of borrowing and loaning between the language forms were "virtually continuous" (p. 111). Annotated kanji texts of the kambun kundoku kind, for example, came to be accepted as Japanese literature, not as a second-rate substitute for readers with incomplete knowledge of Chinese. Even with the linguistically valid alternative of 
translation to kana at hand, there was little motivation to actually implement this option. The syncretism that drew deeply from parallel traditions, foreign and indigenous, resulted in a multilingual enrichment of literary creation (Wakabayashi 2005).

A case in point of the productive interaction between the two traditions, from the Edo period (in this case, not an example of syncretic combination), is given by Watson (1990). The zekku form of kanshi, if we recall, consists of a quatrain of five or seven characters per line. Since in Chinese, each morpheme that characters represent is also a syllable, the shorter zekku would attain a length of twenty syllables, only three longer than the famously popular (indigenous) seventeen-mora haiku. This approximation may have contributed to the popularity of the nearly as concise kanshi form, as well as having influenced its style and conception (p. xv).

Two interesting studies of writing system and poetic discourse focus on the duality of Japanese literacy and how it provides creative writers with language and orthography-specific aesthetic resources. The modern day techniques, analyzed by Takanashi (2007) and Takashi Wilkerson/Wilkerson (2000), remind us of similar resources drawn from the vast bilingual and orthographic diversity of previous historical periods.

The first study is about the currently popular practice of inserting interlinear glosses (typically printed above a word or passage of text), an inheritor of the kambun kundoki and other annotation systems. Among modern orthographies, the insertions are probably exceptional in their complexity and specific to the hybrid system of Japanese writing, interfacing, uniquely in the manner that they do, phonology and semantics. In the case of the interlineal gloss, writers are able to exploit possibilities of manipulating graphic and language pattern for building poetic constructions. Bilingual glosses are even observed in some texts. If in large part the poetic function consists in a kind of metalinguistic shift of attention (for artistic purpose) to language pattern (e.g., by violating grammatical expectation, backgrounding communicative function, use of unfamiliar repetition), special extensions of interlinear text annotation serve this function in a number of ways:

- applying unexpected or marked script choice (kanji, kana, alphabetic romanji),

- using an unusual combination of scripts for cross-language switching and borrowing (e.g., kanji for its phonetic value), and

- exploiting a wider latitude in borrowing from foreign languages (spell-out in kana or romanji, gloss in kanji).

Overall, the richness and complexity of the hybrid writing system lends itself to exploring non-standard and experimental styles (Takashi Wilkerson/Wilkerson, 2000).

The kyoka, based on the traditional waka (thirty-one morae, 5-7-5-7-7), is a humorous poem turning on a pun. By confronting the syllable (or mora), in kana, and the morpheme, in kanji, it directs readers through different processing routes for resolving ambiguity. By creating garden path effects, one meaning emerges faster than another, and because word meanings are often associated with either the kana graph or the Chinese character, conflicts arise with contextual information. The tension generated by the incompatible frames produces the poetic effect (Takanashi 2007). As in the example of the gloss and annotation, irregularity is a source of creative construction (a term borrowed from the field of second language learning). 
In adopting and modifying a foreign writing system for its literature, mastery of the medium has been naturally irregular and variable, like second language ability and other kinds of interaction between different language systems always are. The idea here is that this turns out to be a good thing for poetry. In the case of Japanese poetic forms we can consider the possibilities of an intertextuality sui generis: not just between texts and types of text and genre, but between two (not even counting romanji) orthographic systems brought together into a combined super-system, in turn tracing historic linguistic connections to Chinese. For instance, kanshi poetic texts with their full complement of annotation, as for shigin performance, are integratively intertextual in this way. The two non-standard uses of writing in poetry just mentioned, in kyoka and in interlineal gloss, suggest interesting cross-language possibilities for modern day kanshi, of an experimental kind for example, annotated such as to explore bilingual readings.

\subsection{In what way might Chinese characters be exceptional?}

The recent re-edition of The Chinese written character as a medium for poetry (Fenollosa/Pound: 2008/1918) deserves our attention in this concluding subsection if for no other reason because of the discussion it may spark on some of the issues raised so far related to orthography and creative writing. The work is certainly of historical interest in large measure due to Ezra Pound's participation in the preparation of its final version. But it needs to be recognized that as part of the history of foreign interest in Chinese culture it shows how far off the mark the early attempts at understanding aspects of its language and writing actually were. ${ }^{8}$ It turns out in fact that none of the substantive hypotheses put forward about the Chinese language or writing system would be confirmed by subsequent empirical study (not to be taken, of course, as a dismissal of the authors' proposals for poetics, which is a separate and interesting discussion). And clearly, their assessment of the special features of Chinese writing as these might be related to poetry was unquestionably well-intentioned as is evident from the general tenor of the essay, written at the turn of the $19^{\text {th }}$ century, an important historical detail not to forget. Nevertheless, serious misconceptions underlie their claims about both writing system and language, today presented anew in a 2008 edition. For replies to the essay, see Liu (1966) and Xie (1999), and for a summary of research findings in the field of literacy in Chinese, Tzeng/Hung (2002), Perfetti (2003) and Francis (2010).

Coinciding with popular notions, which notably have persisted in some quarters until recent years, Chinese characters appeared to Fenollosa and Pound (2008/1918) as "visible hieroglyphs." More than arbitrary symbols (e.g., as in alphabetic writing), according to the authors, they are "based upon a vivid shorthand picture of the operations of nature" (p. 43). Characters in this way being more "natural," the Chinese language would also be more "dramatic," and its poetry speaking at once with the "vividness of painting and with the

\footnotetext{
${ }^{8}$ An interesting speculation might be to trace a path from Pound's theory of the Chinese language and its writing system through to subsequent aesthetic insights about poetics, as in his contribution to the Imagist school. The former having been founded on incorrect conceptions, the interest then would be to identify the discontinuities that turned out to favor coherence in the latter. Weinberger (2003) suggests that drawing such a distinction (that the "mistake was fruitful," p. xxi) might help us sort out the outstanding contradictions at hand. This proposed approach, by the way, appears to be very different from that of the critical introduction to the new edition of The Chinese written character (Saussy 2008).
} 
mobility of sound." Reading, then, is like "watching things" (p. 45). But far from "semipictoral" (p. 43), the system of characters constitutes a fully formed, language-based, modern orthography, linked to the sound system and morphology of the Chinese language. In reading, the growing consensus among researchers is that phonology cannot be by-passed when decoding for meaning, just as it cannot be by-passed in Japanese kana or in reading an alphabetic script (Toyoda/Scrimgeour 2009). The few examples given in the essay of simple characters of the pictographic type come from the small subset representing a vestige of early Chinese writing in its ancient origins during the Shang Dynasty (1200-1050 BCE), perhaps earlier. The vast majority of characters are of the so-called compound type which include a phonetic subcomponent (radical); characters' corresponding semantic radical often provides a clue to a category or concept, but overall does not indicate directly, in a reliable way, a specific meaning. In other words, there is no "picture writing" (p. 53), "natural connection between thing and sign" (p. 45) that does not activate linguistic competence, Chinese-specific "concrete force" (p. 50), or privileged and exceptional "visibility" of metaphor that circumvents language (p. 55).

On the authors' account, by means of a unique feedback loop, Chinese writing seems to have re-formed the language itself. It apparently knew no grammar except the one that Europeans and Japanese imposed upon it (p. 51). The idea that Chinese was "able to retain its original creative poetry with far more vigor and vividness than any phonetic tongue" (p. 55) betrays a common belief, still widely held, in the power that cultural acquisitions wield over foundational competencies of human cognition. To the contrary, no spoken language, Chinese included, can be any less phonetic than any other; and without exception, all are independent of the effects of orthography in this regard. In addition, phonological competence is part of the mental grammar of all language knowledge, different from what is termed "invented...grammar" (p. 50), of the prescriptive kind (again to be fair to Fenollosa and Pound, a distinction only recently well understood).

Surprising, however, is the assertion that "uninflected languages like English and Chinese" adhere closer to a "natural order," a "stronger reliance upon verbs" and a speech more compatible with a "kind of dramatic poetry" (p. 48). The ideal test of this claim would be to contrast the aesthetic properties of (non-adapted, purely Chinese-style) kanshi and waka, the latter dependent on Japanese inflectional morphology and a hypothetically unnatural syntax. Fortunately for both linguistic theory and poetics, few Japanese literary historians would probably rank waka across the board as inferior to kanshi - the other way around would be the case, if anything. The surprise in the claim about how Chinese characters affected both the spoken language and its poetry so profoundly is that the authors seem to have lost sight of the basic fact that poetry is ancestral to written literature, everywhere, in all cultures, being an art form fundamentally/primitively not born of literacy. In this sense, poetry is a verbal art (and manual-language art, difficult topic for another occasion). Its precursors are to be found in the oral tradition, the musical properties of the human voice, and the (grammatical) patterns of language. In the final analysis, in historical terms, written poetry is a secondary emergence.

There are exceptional properties of the Chinese writing system, which for example may have participated uniquely in the development of Japanese literature; as much was suggested in Section 3.3 as a proposal for future investigation. No other modern writing system utilizes graphemes with properties similar to those of the Chinese character (kanji in Japan); and 
together with some of the distinguishing characteristics of Chinese grammar there are interesting problems that can be explored further about how the poetic traditions of East Asia that have shared one or another of these orthographic and/or linguistic features may have been influenced by them. For example, such distinguishing characteristics might include: its economy in morphology and syntax, tone in lexical phonology and how it interacts with intonation contour. But the theory of pictographic/ideographic characters simply leads us down the wrong path in trying to formulate the right questions for a research program on cross-language aesthetics. Again, this is entirely separate from how we should assess the contributions of Pound to poetics that may have been inspired by his study of Chinese, and even separate from how we are to evaluate his translations of Chinese poetry.

\section{Conclusion: future directions}

Language, together with primitive music and poetry, emerged once in evolution in the $\mathrm{H}$. sapiens lineage, an emergence that is part of what set early humans apart biologically from their diverging evolutionary cousins (Mithen 2009). In contrast, writing developed recently as a cultural achievement (in the historical past), invented independently, by all accounts, in the Near East-Mediterranean, East Asia and the Americas. This parallel invention of the first word processing technology happens to coincide geographically with our examples of crosslanguage literary creation. (It should be taken as a true coincidence.) But at the same time, unfortunately, the focus in this essay on written forms resulted in not attending to oral tradition poetry and cross-language questions unrelated to differences in writing system. Further investigation should not neglect the different kinds of bilingual interaction in oral tradition and vernacular poetry, or among written genres that share the same orthography. Recall that this was part of the critique in Section 3.4, directed at the hypothesis of Pound and Fenollosa: that morphosyllabic characters resulted in the Chinese language being more natural and dramatic, and its poetry more "vivid." Thus, future research should not overlook the first principles and foundations of poetic language in its ancestral, pre-literate, origin. As was suggested in the previous section, one line of investigation that might inform the question of the special properties of Chinese characters would be a systematic comparison, from different historical periods, of Japanese verse composed in, or mainly in, kanji and verse composed in one of the Japanese syllabic scripts. Modern day reflections of the origin of poetry still proliferate in surviving oral tradition and in vernacular poetry. In this consists, by the way, the enduring contribution of Parry (1987) and Lord (1960).

Literature in minority and indigenous languages, usually sharing the same script as their corresponding majority/national language, face special circumstances in regard to: transcription and translation, influence from languages-in-contact, and diglossic allocation. The conditions and situations more often than not are sharply asymmetrical and often conflictive. For example, what are the most appropriate and operable media for conserving the artistic forms associated with endangered languages? In the past, oral tradition genres tied to musical expression (e.g., the preservation of the romances in North Africa) had showed themselves to be especially effective in regard to conservation. Today, however, it seems that the standard conceptions of diglossia (language choice and language distribution), relevant to favoring the objective of conservation, are less applicable. Thus, one hypothesis to evaluate is whether new media, including standard written and electronic forms, under current 
conditions, favor the preservation and revitalization of traditional poetry among the actual speech communities with which it is associated.

Does writing now, unlike during the epochs of ancient poetry, facilitate cross-language exchange and creativity tied to the sharing of artistic traditions, at least in some domains? For example, does transcription, from oral tradition, have the potential to make verse structure more salient, like it may have been made so by the author(s) of the original Popul Vuh manuscript? Minimally, transcription might reveal verse structure more plainly for purposes of reflection and understanding. Recall that this was the example from the Introduction related to transitions that introduce new borrowed and hybrid forms. Comparative literary research in this case could focus first on modern indigenous-language writers who are bilingual.

Of exploratory and descriptive nature, the above-mentioned comparisons can attend to features such as codeswitching and borrowing, typically applied to the sentence-grammar level, applied now to verse lines. Hypothetically, since poetic language readily, by design, takes license with prosaic morphosyntax, what might be the limits of this transgression of grammar when verse takes bilingual form? That is, assuming again that such limits are in fact imposed (experimental and avant-garde forms aside for now), how might the relevant constraints differ when we compare prosaic and poetic language mixing? ${ }^{9}$ From this point of view, which restrictions will mixed language poetry tend to still preserve as it deviates from the expectations of conversational and prosaic language mixing? Bilingual poetry should tend to exploit this, additional, device of deviation just as unilingual poetry exploits the same resource within the confines of one grammar. For example, following Myers-Scotton's (2006) model, in a bilingual poem an embedded constituent (from the guest language) might be introduced such that a break in grammatical pattern is perceived to occasion an abrupt shift, while at the same time preserving expected grammatical pattern within each constituent. Awkward (but still grammatical) switches from one language to another, on the other hand, might be associated with different kinds of transition or effect of defamiliarization. Recall that the research questions in this case assume, provisionally, that language mixing in verse lines will not deviate so far as to become completely random or unsystematic.

This brings us, finally, to what was the overarching idea for further study suggested in the historical overviews: whether poetic forms lend themselves more productively to crossing language boundaries. The suggestion is related to the possibility that these crossings provide poets with additional creative resources. An important cross-language dimension related to this question is the one that runs along the standard-nonstandard language divide. As

\footnotetext{
${ }^{9}$ In the following hypothetical (prosaic) examples, (1) would be generally considered by a bilingual speaker as well-formed because the inserted (Spanish) constituents are perceived to be integrated into grammatical frame of the sentence as a whole. Example (2) would tend to be judged by a speaker proficient in both Spanish and English as ill-formed. In this case, the grammatical constraints of one or both language subsystems are violated where the insertions occur. See Note 2 for one analytical framework that has been widely applied.

(1) I like that novel, la primera que escribió Carlos Fuentes in nineteen fifty-eight, because it reminds me of my abuelos.

[I like that novel, the first one that Carlos Fuentes wrote in nineteen fifty-eight, because it reminds me of my grandparents.]

(2) *I like that novel, the first one que Carlos Fuentes wrote in nineteen fifty-eight, because it me hace recordar de mis abuelos.

[I like that novel, the first one that Carlos Fuentes wrote in nineteen fifty-eight, because it makes me remember my grandparents.].
} 
Suleiman (2004) points out, the fact that modern poetry might be able to jump this divide more easily is not relevant to the (mis)perception that vernacular dialects are not founded on well-formed grammars. Non-standard language systems are also based on grammatical rulegoverned structures. In reference to the example of standard and vernacular Arabic, the poetic forms in the high classic variety may simply be more constrained (Haeri 2003); and the prosaic norms from which classical verse patterns are derived more likely to be described in dictionaries and textbooks. Modern and experimental forms, in turn more likely to be composed in the vernacular dialects, might also tend to drive poetic derivation (here understood as systematic contravention of grammar) further than would poetry written in the standard variety.

The other side of the idea that poetic forms straddle language boundaries may be their ability to stand above them (as standard writing conventions do), and bring readers of different dialects and even languages together, convergently, on the same texts. This possibility would be especially relevant to speech communities dispersed into diverging dialects, a condition that characterizes many indigenous languages and languages of diaspora. A related observation is made by Halevi-Wise (1998) in regard to the notion of "literary and cultural bridge." In any case, the purportedly greater ability of poetry to exploit cross-language opportunities and reach over linguistic confines (greater than in prosaic genres) is an interesting claim, suggested in the previous sections but not supported yet with confirming evidence. This possibility can be proposed as a working hypothesis for investigations across all language and writing systems. The details of testing this hypothesis will be different in each case study, but the general idea is the same. Again, given the present (very incipient) stage of the work in this area, research will necessarily begin by taking an exploratory and descriptive direction. For example, structured interviews that include native-speaker judgment of different levels of intercomprehensibility can compare responses to texts written, and preformed orally, in contrasting dialects and closely related languages.

Then, at last, is the closely related question that was touched on in the two previous sections: what are the aesthetic resources of cross-language interaction and bilingual processing that poetry in particular is in a position to exploit? Different kinds of interlinguistic transfer and language alternation came up in Sections 2 and 3 as specific instances, but clearly this is an area about which we know very little. Processes of transfer in particular are related to the factor of non-native speaker error as a creative force, as we saw earlier. Similarly, this kind of transfer and error is a creative force in historical change of languages. Such would be an interesting subsidiary research question under the overarching theme of crossing language boundaries.

\section{References}

Addiss, Stephen (1997): "Singing the Wakan Roei Shu". In: Rimer, Thomas/Chaves, Jonathan (eds.) (1997): Japanese and Chinese Poems to Sing: The Wakan Roei Shu. New York, Columbia University Press: 244-259.

Bouras, Karima (2009): "La Literatura Aljamiada: Aproximación General". Actas del Primer Taller Literaturas Hispánicas y Español/Lengua Extranjera. Orán: Instituto Cervantes de Orán. 74-88. http://oran.cervantes.es/

Chejne, Anwar (1980): Historia de España Musulmana. Madrid: Catedra. 
Christianson, Allen (2007): Popul Vuh: Sacred Book of the Ancient Mayas. Norman: University of Oklahoma Press.

Coe, Micahel/Van Stone, Mark (2001): Reading the Maya Glyphs. New York: Thames \& Hudson.

Czöndör, Klára (2008): "La Escritura de la Lengua Judeo-Española". Verbum Analecta Neolatina 10: 79-97.

Damrosch, David (1991): "The Aesthetics of Conquest: Aztec Poetry before and after Cortés." Representations 33: 101-120.

Díaz-Mas, Paloma (1993): Los Sefardies: Historia, Lengua y Cultura. Barcelona: Riopiedras Ediciones.

Díaz-Mas, Paloma (2003): "Escritura y Oralidad en la Literatura Sefardí." Signo: Revista de Historia de la Cultura Escrita 11: 37-57.

Díaz-Mas, Paloma (2005): "Cómo Hemos Llegado a Conocer el Romancero Sefardí." Acta Poética 26: 239-259.

Fenollosa, Ernest/Pound, Ezra (2008/1918): "The Chinese Written Character as a Medium for Poetry". In: Saussy, Haun/Stalling, Jonathan/Klein, Lucas (eds.) (2008/1918): The Chinese Written Character as a Medium for Poetry, A Critical Edition. New York, Fordham University Press: 41-60.

Fraleigh, Matthew (2009): "Songs of the Righteous Spirit: 'Men of High Purpose' and their Chinese Poetry in Modern Japan". Harvard Journal of Asiatic Studies 69: 109-171.

Francis, Norbert (2010): "A Componential Approach for Bilingual Reading and Comparative Writing System Research: The Role of Phonology in Chinese Writing as a Test Case". Language Learning 60: 683-711.

Gargesh, Ravinder (2006): "On Nativizing the Indian English Poetic Medium". World Englishes 25: 359-371.

Garibay, Angel María (1971): Historia de la Literatura Náhuatl. Mexico D.F.: Editorial Porrúa.

Gold, Harold (1975): Liner notes for Shigin. New York: Folkways Records.

Gómez Renau, Mar (2000): "La Lengua Aljamiada y su Literatura: Una Variante Islámica del Español". Castilla: Estudios de Literatura 25: 71-83.

González Palencia, Angel (1928): Historia de la Literatura Arábico-española. Barcelona: Editorial Labor.

Gottlieb, Nanette (2005): Language and Society in Japan. Cambridge: Cambridge University Press.

Hadley, Scott (2008): "La Literatura Bilingüe Náhuatl-Español: Un Espacio de Convivencia entre dos Idiomas". In: González, Luis/Hernúñez, Pollux (eds.) (2008): Actas del III Congreso Internacional 'El Español, Lengua de Traducción' - Traducción, Contacto y Contagio. Puebla, Benemérita Universidad Autónoma de Puebla: 419-438.

Haeri, Niloofar (2003): Sacred Language, Ordinary People: Dilemmas of Culture and Politics in Egypt. New York: Palgrave Macmillan.

Halevi-Wise, Yael (1998): "Puente entre Naciones: Idioma e Identidad Sefardí en Novia que te Vea e Hisho que te Nazca de Rosa Nissan". Hispania 81: 269-277.

Harris, Tracy (1994): Death of a Language: The History of Judeo-Spanish. Newark: University of Delaware Press.

Johansson, Patrick (1993): La Palabra de los Aztecas. Mexico, D.F.: Editorial Trillas. 
Johnson, John William (2006): "Orality, Literacy and Somali Oral Poetry". Journal of African Cultural Studies 18: 119-136.

Kánchev, Ivan (1999): "Solidaridad Lingüística y Tolerancia Religiosa de los Sefardíes Balcánicos". Revista de Filología Románica 16: 59-66.

Kato, Shuichi (1997): A History of Japanese Literature from the Man'yôshû to Modern Times. Richmond, Surrey: Curzon Press.

Kato, Toshihito (2005): "Learning Strategies Employed by Chinese-background Learners in Learning Japanese Vocabulary". Japanese Studies 25: 271-286.

Kenner, Charmian/Al-Azami, Salman/Gregory, Eve/Ruby, Mahera (2008): "Bilingual Poetry: Expanding the Cognitive and Cultural Dimensions of Children's Learning". Literacy 42: 92-100.

Kess, Joseph/Miyamoto, Tadao (1999): The Japanese Mental Lexicon: Psycholinguistic Studies of Kana and Kanji Processing. Amsterdam: John Benjamins.

Kettani, M. Ali (2007): "Lengua y Literatura Aljamiadas". Alif Nûn 52: 1-9.

Lazar, Moshe (1972): The Sephardic Tradition: Ladino and Spanish-Jewish Literature. New York: Norton.

Lee, Jongsoo (2004): "Nezahualcoyotl and the Notion of Individual Authorship in Nahuatl Poetry". Confluencia 20: 73-86.

León-Portilla, Miguel (1996): El Destino de la Palabra: De la Oralidad y los Códices Mesoamericanos a la Escritura Alfabética. Mexico, D.F.: Fondo de Cultura Económica.

León-Portilla, Miguel (2007): "La Música en el Universo de la Cultura Náhuatl". Estudios de Cultura Náhuatl 38: 129-163.

Li, David Chor Sing (2006): "Chinese as a Lingua Franca in Greater China". Annual Review of Applied Linguistics 26: 149-176.

Liman, Taoufik (2002): "Lenguaje Híbrido de los Moriscos: Entre el Arraigo de su Acervo Cultural Islámico y las Vicisitudes del Entorno". Anaquel de Estudios Arabes 13: 67-86.

Liu, James J. Y. (1966): The Art of Chinese Poetry. Chicago: University of Chicago Press.

López, Carlos (2009): "Nuevos Aportes para la Autenticidad del Popul Wuj". Revista Iberoamericana 75: 125-151.

Lord, Albert (1960): The Singer of Tales. Cambridge: Harvard University Press.

Loveday, Leo (1996): Language Contact in Japan: A Socio-linguistic History. Oxford: Clarendon Press.

Mendieta-Lombardo, Eva/Cintrón, Zaida (1995): "Marked and Unmarked Choices of Code Switching in Bilingual Poetry". Hispania 78: 565-572.

Menéndez Pidal, Ramón (1952): Poema de Yúçuf: Materiales Para su Estudio. Granada: Universidad de Granada.

Minervini, Laura (2006): "El Desarrollo Histórico del Judeoespañol". Revista Internacional de Lingüistica Iberoamericana 8: 13-34.

Mithen, Stephen (2009): "The Music Instinct: The Evolutionary Basis of Musicality". Annals of the New York Academy of Sciences 1169: 3-12.

Montemayor, Carlos (2005): "La Poesía en Lenguas Indígenas de México". In: Montemayor, Carlos/Frischmann, Donald (eds.) (2005): Words of the True Peoples/Palabras de los Seres Verdaderos. Austin, University of Texas Press: 11-19.

Montes de Oca, Mercedes (2009): "Los Disfrasimos: Un Rasgo del Lenguaje Ritual". Estudios de Cultura Náhuatl 39: 225-238. 
Myers-Scotton, Carol (2006): Multiple Voices: An Introduction to Bilingualism. Oxford: Blackwell.

Parry, Adam (1987): The Making of Homeric Verse: The Collected Papers of Milman Parry. Oxford: Oxford University Press.

Pérez Lasheras, Antonio (2003): La Literatura del Reino de Aragón hasta el Siglo XVI. Zaragosa: Ibercaja, Institución Fernando El Católico.

Perfetti, Charles (2003): "The Universal Grammar of Reading". Scientific Studies of Reading 7: 3-24.

Rabinovitch, Judith (1996): "An Introduction to Hentai Kambun [Variant Chinese], a Hybrid Sinico-Japanese Used by the Male Elite in Premodern Japan". Journal of Chinese Linguistics 24: 98-127.

Rabinovitch, Judith/Bradstock, Timothy (2005): Dance of the Butterflies: Chinese Poetry from the Japanese Court Tradition. Ithaca: Cornell University.

Rodríguez Martínez/María del Carmen/Ceballos, Ponciano/Coe, Michael/Diehl, Richard/Houston, Stephen/Taube, Karl/Delgado Calderón, Alfred (2006): "Oldest Writing in the New World". Science 313: 1610-1614.

Romero, Elena (2010): "La Polémica sobre el Judeoespañol en la Prensa Sefardí del Imperio Otomano: Más Materiales para su Estudio". Sefarad 70: 435-473.

Sato, Hiroaki (ed.) (1998): Breeze through Bamboo: Kanshi of Ema Saiko. New York: Columbia University Press.

Saussy, Haun (2008): "Fenollosa Compounded: A Discrimination". In: Saussy, Haun/Stalling, Jonathan/Klein, Lucas (eds.) (2008): The Chinese Written Character as a Medium for Poetry, A Critical Edition. New York, Fordham University Press: 1-40.

Suleiman, Yasir (2004): A War of Words: Language and Conflict in the Middle East. Cambridge: Cambridge University Press.

Takanashi, Hiroko (2007): "Orthographic Puns: The Case of Japanese Kyoka". Humor 20: 235-259.

Takashi Wilkerson, Kyoko/Wilkerson, Douglas (2000): "The Gloss as Poetics: Transcending the Didactic". Visible Language 34: 228-262.

Toyoda, Etsuko/Scrimgeour, Andrew (2009): "Common and Script-specific Awareness in Relation to Word Recognition in English and Chinese". Language Awareness 18: 61-73.

Tsujimura, Natsuko (1996): An Introduction to Japanese Linguistics. Oxford: Blackwell.

Tzeng, Ovid J. L./Hung, Daisy L. (2002): "A Phantom of Linguistic Relativity: Script, Speech and Thought". In: Erbaugh, Mary (ed.) (2002): Difficult Characters: Interdisciplinary Studies of Chinese and Japanese Writing. Columbus, Ohio State University: 52-74.

Vail, Gabrielle (2006): "The Maya Codices". Annual Review of Anthropology 35: 497-519.

Vespertino Rodríguez, Antonio (2007): "Análisis del Léxico Aljamiado-morisco Reflejado en la Obra de Muhamad Rabadán". Estudios Románticos 16/17: 883-890.

Wakabayashi, Judy (2005): "The Reconceptualization of Translation from Chinese in $18^{\text {th }}$ Century Japan". In: Hung, Eva (ed.) (2005): Translation and Cultural Change: Studies in History, Norms and Image-Projection. Amsterdam, John Benjamins: 121-145.

Watanabe, Noriko (2002): "Language Planning in Japan: Standardization, Orthography and Internationalization". Geolinguistics 28: 76-90.

Watson, Burton (1968): "Remarks on the Kanshi". The Journal-Newsletter of the Association of Teachers of Japanese 5: 15-21. 
Watson, Burton (trans.) (1976): Japanese Literature in Chinese, Volume II Poetry and Prose in Chinese by Japanese Writers of the Later Period. New York: Columbia University Press.

Watson, Burton (trans.) (1990): Kanshi: The Poetry of Ishikawa Jozan and other Edo-period Poets. San Francisco: North Point Press.

Webster, Anthony (2009): "The Poetics and Politics of Navajo Ideophony in Contemporary Navajo Poetry". Language and Communication 29: 133-151.

Weinberger, Eliot. (2003): The New Directions Anthology of Classical Chinese Poetry. New York: New Directions Books.

Wirtz, Kristina (2005): "Where Obscurity is a Virtue: The Mystique of Unintelligibility in Santería Ritual". Language and Communication 25: 351-375.

Xie, Ming (1999): Ezra Pound and the Appropriation of Chinese Poetry: Cathay, Translation, and Imagism. New York: Garland.

Yiu, Angela (1998): Chaos and Order in the Works of Natsume Soseki. Honolulu: University of Hawaii Press.

Yoshikawa, Kojiro (1955): "Chinese Poetry in Japan: Influence and Reaction". Journal of World History 2: 883-894.

Zucker, George (2001): "Ladino, Judezmo, Spanyolit, El Kasteyano Muestro". Shofar: An Interdisciplinary Journal of Jewish Studies 19: 4-14. 